\title{
PENDAPATAN MASYARAKAT PETANI PENYADAP KARET DI TEMBAWANG DI DESA BANUA TENGAH KECAMATAN PUTUSSIBAU UTARA KABUPATEN KAPUAS HULU
}

\author{
Income of rubber tapping farmers in tembawang in the village of Banua Tengah sub-district \\ Putussibau utara in Kapuas Hulu districts
}

\author{
Melki Kurniason, Fahrizal, Emi Roslinda \\ Fakultas Kehutanan Universitas Tanjungpura Jl. Daya Nasional, Pontianak 78124 \\ E-mail : kurniason28@gmail.com
}

\begin{abstract}
Rubber is a forestry plant producing sap. Rubber latex is needed for various industrial purposes. Rubber is a side business as well as additional income for the community besides farming in Banua Tengah Village. The method used is a survey method with interview techniques. Sampling was done intentionally (purposive sampling). The number of samples taken was 61 respondents who were; rubber farmers, married, worked tapping rubber and owning rubber plantations. Data analysis consists of calculating total income and multiple linear regression analysis. The analysis results obtained total income / Tr received by farmers around Rp. 390,000 - Rp. 2,840,500 / month, when compared to the UMR established by the Government in 2018, UMR Kapuas Hulu Regency is Rp. 2,204,650.00 / month, there are 2 (two) farmers who have an income above the minimum wage while 59 other farmers are still under the UMR There are four factors that influence the income of rubber farmers in Desa Banua Tengah namely land area, work experience, rubber age and workdays, of the four most influential factors are land area and workday variables, while the work experience and rubber age variables are not very influential. Factors of land area, work experience, rubber age and working days together greatly affect farmers' incomes with the equation of total income of rubber farmers as follows: $\ln Y=9,817+0,397 \ln X_{1}+0,098 \ln X_{2}+0,061 \ln X_{3}+1,194 \ln X_{4}$ Correlation value $R=0.928$ and the value of determination $R 2=0.861$ From these equations obtained a constant value of 9,817 which shows that income from rubber farmers $(\hat{Y})$ in Desa Banua Tengah is Rp. 9,817 if $X_{1}, X_{2}, X 3$ and $X 4$ are considered zero. $\hat{Y}$ is positively correlated with $X_{1}, X_{2}, X_{3}$ and $X_{4}$.
\end{abstract}

Keywords: Influential factors, Latex, Rubber farmers, Total income,.

\section{PENDAHULUAN}

Indonesia adalah salah satu produsen karet di dunia, berdasarkan studi IRSG (2007) dalam Boerhendhy et al., (2010), produksi karet alam dunia pada tahun 2020 akan mencapai 13 juta ton dan Indonesia diperkirakan akan menjadi negara penghasil karet alam terbesar di dunia. Potensi untuk menjadi produsen utama karet di dunia dimungkinkan karena Indonesia mempunyai sumber daya yang sangat memadai guna meningkatkan produksi. Peningkatan produksi dapat dilakukan melalui pengembangan areal baru maupun peningkatan produktivitas karet tua, rehabilitasi tanaman, dan intensifikasi dengan menggunakan klon-klon unggul terbaru.

Karet merupakan usaha tani yang dianggap menghasilkan secara pasti bagi petani meskipun permintaan dan 
harga dari karet mengalami penurunan, namun karet tetap mempunyai eksistensi yang tinggi mengingat kebutuhan manusia yang berasal dari bahan karet akan selalu ada dan terus bertambah seiring bertambahnya penduduk dunia.

Karet di Kalimantan Barat biasanya ditanam di dalam lahan tembawang masyarakat lokal. Tembawang adalah sistem penggunaan lahan oleh masyarakat lokal Kalimantan Barat dan merupakan suatu ekosistem unik dengan nilai ekonomis, nilai keanekaragaman hayati dan nilai konservasi yang tinggi, di dalam tembawang terdapat berbagai jenis tumbuhan mulai dari tanaman sumber makanan (buah-buahan), hingga dengan tanaman yang dimanfaatkan kayunya (tengkawang,meranti,dll), serta non kayu (biji tengkawang, karet, dan tanaman obat-obatan) terdapat di dalam tembawang. Selain ditanam, banyak juga tumbuhan yang tumbuh secara alami dari proses regenerasi alam (ITTO,2011).

Desa Banua Tengah merupakan salah satu desa di Kalimantan Barat yang berada didalam kawasan hutan yang cukup luas, sebagian besar masyarakatnya masih sangat bergantung dengan kebun karet dan tembawang, misalnya pada musim buah: durian, langsat dan tengkawang. Dalam peningkatan pendapatan dari HHBK setiap tahunnya cenderung tidak ada perkembangan sehingga tingkat kesejahteraan rakyatnya masih dikatakan sangat-sangat kurang. Usaha yang cukup menjanjikan tersebut diantaranya adalah usaha tani karet dan pengelolaan hutan tembawang yang selama ini sudah cukup dikenal oleh masyarkat Indonesia khususnya suku Dayak di Kalimantan Barat.

Pada akhir tahun 2017 lalu harga karet di Indonesia khususnya jatuh ke harga enam ribu rupiah/kilo, sehingga banyak masyarakat tani beralih ke pekerjaan lain yang dianggap lebih menguntungkan, sehingga diperlukan penelitian khusus untuk menghitung seberapa besar pendapatan masyarakat dari karet, antara lain uraian permasalahannya adalah sebagai berikut : mengetahui berapa banyak penerimaan dan pendapatan kotor masyarakat dari usaha tani karet, serta mengetahui faktor - faktor apa saja yang mempengaruhi pendapatan dari usaha tani karet.

Penelitian ini bertujuan untuk, menganalisa pendapatan masyarakat dari karet, dan mengetahui faktor-faktor yang mempengaruhi pendapatan dari karet.

\section{METODE PENELITIAN}

Penelitian dilaksanakan di Desa Banua Tengah Kabupaten Kapuas hulu dengan Metode penelitian adalah metode survey. Objek dari penelitian ini adalah masyarakat yang berada di Desa Banua Tengah yang umumnya memiliki kebun karet. Pengambilan sampel di lakukan dengan cara sengaja (Purposive Sampling).

Alat yang digunakan dalam penelitian ini adalah alat berupa :

1. Software (SPSS) versi 20 dan program Excell windows 7 untuk mengolah data. 
2. Kamera untuk dokumentasi dalam penelitian.

3. Daftar pertanyaan berupa kuisioner

Data yang dikumpulkan terdiri dari dua jenis data yaitu data primer dan data sekunder. Data primer diperoleh dari teknik komunikasi lapangan dengan responden menggunakan kuisioner dalam bentuk daftar pertanyaan yang sudah disiapkan. Data sekunder diperoleh dari berbagai sumber yang terkait dengan penelitian. Data sekunder meliputi keadaan iklim, luas wilayah, komposisi penduduk di Banua Tengah, keadaan sosial ekonomi penduduk, dan peta lokasi penelitian dari kantor kelurahan.

Menurut Sugiharsono dan Daru Wahyuni (2019) untuk mengetahui jumlah penerimaan/Pendapatan total (Tr) yang diperoleh dari penjualan lateks karet dapat dihitung dengan menggunakan rumus :

$\mathrm{TR}=\mathrm{P} \times \mathrm{Q}$

Dimana :

$\mathrm{TR}=$ total penerimaan $(\mathrm{Rp})$

$\mathrm{P}=$ harga produk $(\mathrm{Rp})$

$\mathrm{Q}=$ jumlah Produk $(\mathrm{Kg})$

Data yang diperoleh saat penelitian di uji dengan uji asumsi dasar dan empat asumsi dasar (klasik) untuk program SPSS 20. yang terdiri dari :

Uji asumsi dasar yaitu : a. uji normalitas

b. uji linieritas

Uji asumsi klasik yaitu :

a. Multikolinieritas

b. Heteroskedastisitas, dan

c. uji autokorelasi.

Ketika sudah memenuhi uji asumsi dasar klasik kemudian baru di olah data ke pengolahan data berikutnya yaitu analisis regresi linier berganda.

Menurut Daniel (2003) dalam Suraini (2015) untuk melihat hubungan atau pengaruh dari dua atau tiga (dan atau lebih) variabel independen terhadap satu variabel dependen maka digunakan rumus :

$\mathbf{Y}=\mathbf{b}_{0}+\mathbf{b}_{1} \mathbf{X}_{1}+\mathbf{b}_{2} \mathbf{X}_{2}+\mathbf{b}_{3} \mathbf{X}_{3}+\mathbf{b}_{4} \mathbf{X}_{4}+e$

Dimana :

$\mathrm{Y}=$ pendapatan (pendapatan total/TR) petani penyadap karet

$\mathrm{b}_{0}=$ konstanta

$\mathrm{b}_{1 .,}=$ koefisien regresi

$\mathrm{x}_{1}=$ luas lahan karet $(\mathrm{Ha})$

$\mathrm{x}_{2}=$ pengalaman kerja (Tahun)

$\mathrm{x}_{3}=$ umur karet yang disadap (Thn).

$\mathrm{x}_{4}=$ hari kerja dalam satu bulan (Hri)

$\mathrm{e}=$ error $1 \%(0,01)$

\section{HASIL DAN PEMBAHASAN}

\section{Identitas Responden}

Identitas responden terdiri dari umur petani karet, pendidikan dan jenis kelamin petani penyadap karet. Umur petani karet dapat dilihat pada Tabel.1 sebagai berikut:

Tabel 1. Umur Petani Karet (The Age of Rubber Farmers)

\begin{tabular}{clcc}
\hline Umur petani (Thn) & Kategori umur & Jumlah (Jiwa) & Persentase (\%) \\
\hline $23-35$ & Masa Remaja Akhir & 14 & 22,95 \\
$36-49$ & Masa Dewasa Akhir & 27 & 44,26 \\
$50-60$ & Lansia & 20 & 32,78 \\
\hline Jumlah & & 61 & 100 \\
\hline
\end{tabular}

Sumber : Analisis data 2018. 
Pada Tabel.1 dapat disimpulkan bahwa petani karet di Desa Banua Tengah masih banyak dilakukan oleh petani yang masih tergolong produktif yaitu dengan usia 36 - 49 tahun dengan persentase yang cukup tinggi sebesar $44,26 \%$.
Pendidikan petani dengan rincian sebagai berikut ini, tamatan Sekolah Menengah sebanyak responden, SD sebanyak 16 responden, dan terdapat juga petani yang tidak Tamat Sekolah sebanyak 8 responden.

\section{Tabel 2. Pendidikan Petani Karet (Rubber Farmer Education)}

\begin{tabular}{lcc}
\hline \multicolumn{1}{c}{ Tingkat Pendidikan } & Jumlah (Jiwa) & Persentase (\%) \\
\hline Sekolah Menengah & 37 & 60,65 \\
Sekolah Dasar & 16 & 26,22 \\
Tidak Tamat Sekolah & 8 & 13,11 \\
\hline \multicolumn{1}{c}{ Jumlah } & 61 & 100 \\
\hline
\end{tabular}

Sumber : Analisis data 2018

Pada Tabel 2 dapat disimpulkan jumlah 37 orang petani dengan bahwa sebagian besar petani karet merupakan tamatan sekolah menengah baik tingkat SMP maupun SMA dengan

persentase mencapai $60,65 \%$.

Jenis kelamin responden yang banyak melakukan penyadapan karet adalah laki-laki, sedangkan perempuan hanya terdapat 5 orang saja.

Tabel 3. Perbandingan Berdasarkan Jenis Kelamin Petani Karet (Comparison Based on the Sex of Rubber Farmers)

\begin{tabular}{lcc}
\hline Jenis kelamin & Jumlah (Jiwa) & Persentase (\%) \\
\hline Laki-laki & 56 & 91,80 \\
Perempuan & 5 & 8,19 \\
\hline Jumlah & 61 & 100 \\
\hline
\end{tabular}

Sumber : Analisis data 2018

Pada Tabel 3 dapat disimpulkan

Curahan tenaga kerja petani dalam bahwa petani penyadap karet sebagian besar dilakukan oleh Laki-laki.

2. Curahan Tenaga Kerja, Waktu Kerja dan Produksi Karet

Tabel 4. Waktu Kerja (Working Time)

\begin{tabular}{cccc}
\hline Waktu kerja (jam)/hari & Keterangan & Jumlah (Jiwa) & Persentase (\%) \\
\hline $1,1-2,8$ & Pendek & 42 & 68,85 \\
$2,9-4,5$ & Sedang & 18 & 29,50 \\
$4,6-6$ & Panjang & 1 & 1,63 \\
\hline Jumlah & & 61 & 100 \\
\hline
\end{tabular}

Sumber : Analisis data 2018

Pada penelitian ini hanya mewakili 1 (satu) orang pekerja untuk mengetahui

lamanya suatu pekerjaan terutama Tabel 5. Produksi Karet (Rubber Production)

\begin{tabular}{cccc}
\hline Produksi karet $\mathbf{( K g )} / \mathbf{h a r i}$ & Keterangan & Jumlah (Jiwa) & Persentase (\%) \\
\hline $6-10$ & Sedikit & 38 & 62,29 \\
$11-15$ & Sedang & 22 & 36,06 \\
$16-19$ & Banyak & 1 & 1,63 \\
\hline Jumlah & & 61 & 100 \\
\hline
\end{tabular}

Sumber : Analisis data 2018 
Pada Tabel.5 produksi karet berdasarkan persentase paling besar yaitu $6-10 \mathrm{~kg}$ yang berarti sebagian besar produksi karet dari petani di Desa Banua Tengah masih tergolong sedikit.

Karet yang dihasilkan Petani adalah getah karet yang di tampung dalam wadah (tempurung) kemudian di tinggalkan dan tanpa dicetak karena sebagian besar petani menganggap cara ini lebih praktis dan cepat. Syamsulbahri (2006), dalam Ulfah Diana et al., (2015) semakin bertambah umur tanaman karet maka semakin meningkat produksinya, setelah mengalami masa stabil kemudian akan mengalami penurunan produksi. Faktorfaktor alami yang mempengaruhi produksi karet yaitu : besarnya curah hujan, suhu harian rata-rata, ketinggian tempat dari permukaan laut, dan intensitas sinar matahari adalah hal yang sangat dibutuhkan tanaman karet (Tim Penulis PS, 1999).

\section{Pendapatan (Pendapatan Total/TR) Petani Karet.}

Pendapatan (pendapatan Total/TR) petani karet adalah hasil dari perkalian dari harga produk dengan jumlah produk, dalam penelitian ini khususnya harga karet yang berlaku pada saat penelitian dikalikan dengan jumlah berapa kilo gram getah petani yang dijual ke penampung/pembeli. Pada saat dilaksanakannya penelitian harga karet dalam per kilonya Rp 6500,00 namun kadang-kadang pada kenyataannya dalam satu tahun terjadi penurunan dan kenaikan harga. Menurut Sukirno (2002) dalam Wijayanti dan Saefuddin (2012), Untuk mengetahui jumlah penerimaan yang diperoleh dari usaha tani dapat dihitung dengan menggunakan rumus :

$\mathrm{TR}=\mathrm{P} \times \mathrm{Q}$

Dimana :

$\mathrm{TR}=$ total penerimaan $(\mathrm{Rp})$

$\mathrm{P} \quad=$ harga produk $(\mathrm{Rp})$

$\mathrm{Q}=$ jumlah Produk $(\mathrm{Kg})$

Tabel 6. Pendapatan (Pendapatan Total/TR) Petani Karet (Income (Total Income ) TR) of Rubber Farmers).

\begin{tabular}{cccc}
\hline $\begin{array}{c}\text { Pendapatan total/TR } \\
\text { (Rp/bulan) }\end{array}$ & Keterangan & Jumlah (Jiwa) & Persentase (\%) \\
\hline $390,000-1.207,000$ & Rendah & 33 & 54,09 \\
$1.208,000-2.025,000$ & Sedang & 26 & 44,26 \\
$2.026,000-2.840,500$ & Tinggi & 2 & 1,63 \\
\hline Jumlah & & 61 & 100 \\
\hline
\end{tabular}

Sumber : Analisis data 2018

Berdasarkan hasil penelitian pada Tabel 6 pendapatan petani karet sangat bervariasi dari pendapatan petani terendah sebesar $\operatorname{Rp} 390,000$, dan tertinggi mencapai sebesar $\mathrm{Rp}$ 2.840,500. Jika dibandingkan dengan UMR kabupaten kapuas hulu pada tahun 2018 perbulannya mencapai Rp.2.204.650,00 sehingga terdapat dua orang petani pendapatannya diatas gaji UMR Kabupaten Kapuas Hulu. Hasil penelitian ini sesuai dengan pernyataan Almasdi Syahza, (2015) yang menyatakan bahwa Peningkatan dan perubahan pendapatan petani akan dipengaruhi oleh dua unsur penting yaitu unsur produksi yang diperoleh dari usaha tani dan tingkat harga yang diterima petani.

4. Faktor-Faktor yang Mempengaruhi Pendapatan 
Faktor-faktor yang mempengaruhi Luas lahan dan Pengalaman Kerja pendapatan petani karet adalah sebagai Petani Karet.

berikut :

Tabel 7. Luas lahan (Land Area)

\begin{tabular}{clcc}
\hline Luas lahan (Ha) & \multicolumn{1}{c}{ Keterangan } & Jumlah (Jiwa) & Persentase (\%) \\
\hline $0,9-2,3$ & Sempit & 56 & 91,80 \\
$2,4-3,6$ & Sedang & 4 & 6,55 \\
$3,7-4,2$ & Luas & 1 & 1,63 \\
\hline Jumlah & & 61 & 100 \\
\hline
\end{tabular}

Sumber : Analisis data 2018

Petani yang mempunyai luas lahan $0,9-$

termasuk ke dalam petani yang 2,3 hektar berjumlah 56 orang mempunyai lahan karet dengan luas sedangkan sisanya hanya 1 orang sekitar 3,7-4,2 hektar.

Tabel 8. Pengalaman Kerja (Work Experience).

\begin{tabular}{cccc}
\hline Pengalaman kerja (Tahun) & Keterangan & Jumlah (Jiwa) & Persentase (\%) \\
\hline $10-22$ & Pemula & 30 & 49,18 \\
$23-36$ & Biasa & 29 & 47,54 \\
$37-47$ & Berpengalaman & 2 & 3,27 \\
\hline Jumlah & & 61 & 100 \\
\hline
\end{tabular}

Sumber : Analisis data 2018

Pengalaman kerja petani karet mulai dari 10 tahun hingga 47 tahun ini dikarenakan memang Desa Banua Tengah sudah menjadi lahan bisnis khususnya bagi penampung kulat karet.

\section{Umur karet dan Hari kerja}

Umur karet yang disadap petani di Desa Banua Tengah pada hasil penelitian didapatkan umur karet yang paling muda 7 tahun dan paling tua mencapai $40 \quad$ (tahun)

Tabel 9. Umur Karet (Rubber Age)

\begin{tabular}{cccc}
\hline Umur karet (Tahun) & Keterangan & Jumlah (Jiwa) & Persentase (\%) \\
\hline $7-17$ & Muda & 18 & 29,50 \\
$18-29$ & Sedang & 30 & 49,18 \\
$30-40$ & Tua & 13 & 21,31 \\
\hline Jumlah & & 61 & 100 \\
\hline
\end{tabular}

Sumber : Analisis data 2018

Hari kerja yang dimaksud dalam penelitian adalah hari dimana petani karet melakukan penyadapan dalam

satuan hitungan pendapatan yaitu perbulan.

Tabel 10. Hari Kerja (Working Days).

\begin{tabular}{cccc}
\hline Hari kerja (Hari) & Keterangan & Jumlah (Jiwa) & Persentase (\%) \\
\hline $10-13$ & Sedikit & 5 & 8,19 \\
$14-18$ & Sedang & 5 & 8,19 \\
$19-23$ & Banyak & 51 & 83,60 \\
\hline Jumlah & & 61 & 100 \\
\hline
\end{tabular}

Sumber : Analisis data 2018

Pada hasil penelitian dan pada tabel dapat disimpulkan bahwa hari kerja petani karet paling sedikit 10 hari hingga ke hari kerja paling banyak 23 hari dalam satu bulan. Hari kerja dengan persentase paling 
banyak iyalah $19-23$ hari dengan nilai persentase mencapai $83,60 \%$.

\section{Uji Asumsi Dasar.}

Analisis regresi berganda memerlukan beberapa asumsi yaitu asumsi dasar dan asumsi klasik agar model regresi layak dipergunakan. Menurut Priyatno,D (2010).

\section{a. Uji Normalitas}

Data pertama terjadi ketidaknormalan data, maka kemudian data ditransfomasikan kedalam bentuk $\ln$ (logaritma natural) setelah data ditransformasikan maka didapatlah data yang sudah berdistribusi secara normal. Uji normalitas residual menggunakan uji one sample Kolmogorov Smirnov digunakan untuk mengetahui distribusi data, apakah mengikuti distribusi normal,poisson, uniform, atau ekponential. menurut Priyatno D (2018) untuk mengetahui apakah distribusi residual terdistribusi normal atau tidak dapat dilihat dari nilai signifikansi harus lebih dari 0,05.bedasarkan hasil uji normalitas residual data dimana nilai signifikansi harus lebih dari 0,05 pada hasil penelitian maka dengan demikian data sudah berdistribusi normal.

\section{b. Linearitas}

Uji linearitas digunakan untuk mengetahui linearitas data,yaitu apakah dua variabel mempunyai hubungan yang linear atau tidak. menurut Priyatno,D (2018) uji linearitas biasanya digunakan sebagai prasyarat dalam analisis korelasi pearson. pengujian data SPSS dengan menggunakan Test For Linearity pada taraf signifikansi 0,05 dua variabel yaitu satu varibel terikat dan satu variabel bebas dikatakan mempunyai hubungan yang linear bila signifikansi (pada kolom Deviation for Linearity) lebih dari 0,05 atau teori lain mengatakan jika signifikansi ( pada kolom F Linearity ) kurang dari 0,05. akan dikatakan linear.

a) Pada hasil penelitian diperoleh nilai signifikansi pada kolom Deviation From Linearity sebesar 0,876. Signifikansi lebih dari 0,05 dan nilai dari linearity lebih kecil dari 0,05 sehingga dapat disimpulkan bahwa antara variabel pendapatan dengan variabel luas lahan terdapat hubungan yang linear

b) Pada hasil penelitian diperoleh nilai signifikansi pada kolom Deviation From Linearity sebesar 0,170. Signifikansi lebih dari 0,05 namun pada kolom linearity lebih besar dari 0,05 sehingga dapat disimpulkan bahwa antara variabel pendapatan dengan variabel pengalaman kerja terdapat hubungan yang tidak linear.

c) Pada hasil penelitian diperoleh nilai signifikansi pada kolom Deviation From Linearity sebesar 0,799. Signifikansi lebih dari 0,05 namun pada kolom linearity lebih besar dari 0,05 sehingga dapat disimpulkan bahwa antara variabel pendapatan dengan variabel umur karet terdapat hubungan yang tidak linear.

d) Pada hasil penelitian diperoleh nilai signifikansi pada kolom Deviation From Linearity sebesar 0,350. Signifikansi lebih dari 0,05 dan nilai dari linearity lebih kecil dari 0,05 sehingga dapat disimpulkan bahwa antara variabel pendapatan dengan 
variabel hari kerja terdapat hubungan yang linear.

\section{Uji Asumsi Klasik}

Menurut Priyatno,D (2018) dalam regresi inier berganda terdapat asumsi klasik yang harus terpenuhi, yaitu data harus berdistribusi normal, tidak adanya, multikolinearitas, heteroskedasitas, dan tidak adanya autokorelasi pada model regresi.

\section{a. Uji Multikolinearitas}

Uji multikolinearitas digunakan untuk mengetahui ada atau tidanya hubungan linear antar variabel independen dalam model regresi. metode pengujian multikolinearitas dalam penelitian ini mengacu pada pendapat Priyatno,D (2018) Berdasarkan hasil penelitian pada uji multikolinearitas dari semua variabel bebas yaitu luas lahan, pengalaman kerja, umur karet dan hari kerja mempunyai nilai VIF (Variance Inflation Factor) kurang dari 10 dan mempunyai angka Tolerance lebih dari 0,1. Dengan demikian dapat disimpulkan bahwa tidak terjadi masalah multikoliearitas pada model regresi.

\section{b. Uji Heteroskedasitas}

Menguji ada tidaknya terjadi heteroskedasitas dalam penelitian dilakukan uji Spearman's rho dengan mengkolerasikan nilai-nilai (Unstandardized Residual ) dengan masing-masing variabel independen. Apabila nilai signifikan kurang dari 0,05 maka pada model regresi terjadi masalah Heterosedasitas (Priyatno, D,2010). Output correlation pada hasil penelitian diketahui korelasi semua variabel bebas dengan unstandardized residual menghasilkan nilai Signifikan (Sig, (2Tailed) lebih besar dari nilai 0,05 , dengan demikian dapat disimpulkan pada model regresi tidak ada permasalahan heteroskedasitas.

\section{c. Uji Autokorelasi}

Autokorelasi adalah keadaan dimana pada model regresi ada korelasi antara residual pada periode $\mathrm{t}$ dengan residual pada periode sebelumnya ( $\mathrm{t}-1)$ (Priyatno,D, 2018) Persamaaan regresi yang baik adalah tidak memiiki masalah autokorelasi,jika terjadi autokorelasi maka persamaan tersebut tidak baik bahkan tidak layak digunakan . ukuran dalam menentukan ada tidaknya masalah autokorelasi dilakukan dengan uji DurbinWatson (DW).

Tabel 11. Uji Autokorelasi (Autocorrelation Test)

\begin{tabular}{cccccc}
\hline Model & $\mathbf{R}$ & $\begin{array}{c}\mathbf{R} \\
\text { Square }\end{array}$ & $\begin{array}{c}\text { Adjusted R } \\
\text { Square }\end{array}$ & $\begin{array}{c}\text { Std. Error of the } \\
\text { Estimate }\end{array}$ & Durbin-Watson \\
\hline 1 &, $928^{\mathrm{a}}$ & 0,861 & 0,851 & 0,156 & 1,429 \\
\hline
\end{tabular}

Sumber : Analisis data 2018

Pada Tabel 11. diperoleh nilai Durbin-Watson (DW) sebesar 1,429. dari nilai Dw diatas, dapat diketahui bahwa nilai Durbin-Watson $\mathrm{k}=4$ jumlah sampel / $\mathrm{N}=61$ diperoleh nilai $\mathrm{DL}=1.322$ dan niali $\mathrm{DU}=1.523$ pada tabel Durbin-Watson (DW) taraf $1 \%$ $(0,01)$ maka nilai DW terletak diantara
$1,322<1,429<1,523$ maka dengan demikian dapat disimpulkan tidak ada kepastian atau tanpa kesimpulan.

\section{Uji Koefisien Determinasi $\left(\mathbf{R}^{\mathbf{2}}\right)$}

Uji koefisien determinasi atau kuadrat dari $\mathrm{R}$, yaitu menunjukan koefisien determinasi. angka $\mathrm{R}$ Square $\left(R^{2}\right)$ akan diubah ke bentuk persen yang 
artinya persentase sumbangan pengaruh variabel independen terhadap variabel dependen (Priyatno D, 2018). Nilai $\mathrm{R}^{2}$ sebesar 0,861, artinya, persentase sumbangan pengaruh variabel luas lahan, pengalaman kerja, umur karet dan hari kerja terhadap pendapatan total petani karet adalah sebesar $86,1 \%$, sedangkan sisanya dipengaruhi oleh variabel lain yang tidak dimasukan kedalam model.

8. Analisa Faktor yang Mempengaruhi Pendapatan Petani Karet

Pada data awal data tidak memenuhi uji normalitas sehingga data ditransformasikan kedalam bentuk Log natural (ln) dengan pendekatan ols (ordinary least square ), sehingga terbentuk persamaan regresi linear berganda yang dapat diekspresikan dalam bentuk persamaan yang menghubungkan variabel terikat (ln y) dengan variabel bebas ( $\ln \mathrm{x}_{\mathrm{i}}$ ) dengan model analisis regresi linear berganda dengan menggunakan pendekatan ols adalah sebagai berikut (Nachrowi dan Hardius Usman,2006)

$\ln Y=b_{0}+b_{1} \ln X_{1}+b_{2} \ln X_{2}+b_{3} \ln X_{3}+$ $b_{4} \ln X_{4}+e$

Dimana :

ln $\mathrm{Y}=$ pendapatan (pendapatan total/TR) petani penyadap karet

$\mathrm{b}_{0} \quad=$ konstanta

$\mathrm{b}_{1}, \mathrm{~b}_{2}=$ koefisien regresi

$\ln \mathrm{x}_{1}=$ luas lahan karet $(\mathrm{Ha})$

$\ln \mathrm{x}_{2}=$ pengalaman kerja (Tahun)

$\ln \mathrm{x}_{3}=$ umur karet yang disadap (Thn).

$\ln \mathrm{x}_{4}=$ hari kerja dalam satu bulan (Hri).

e $\quad=$ error : $1 \%(0,01)$

Berdasarkan pada hasil penelitian diperoleh nilai-nilai pada output, kemudian dimasukkan ke dalam persamaan regresi linear berganda sebagai berikut :

$\ln \mathrm{Y}=9,817+0,397 \ln \mathrm{X}_{1}+0,098 \ln \mathrm{X}_{2}+$ $0,061 \ln X_{3}+1,194 \ln X_{4}$
Penjelasan dari persamaan regresi dan hasil uji secara parsial (uji t) yakni pengaruh variabel bebas terhadap variabel terikat (Pendapatan total/Tr petani penyadap karet di Desa Banua Tengah) sebagai berikut :

\section{Nilai Konstanta}

Nilai konstanta $\left(b_{0}\right)$ adalah 9,817. artinya, jika luas lahan, pengalaman kerja, umur karet dan hari kerja adalah 0 maka tingkat penjualan nilainya positif yaitu 9,817 .

\section{Pengaruh Luas lahan $\left(\mathbf{X}_{1}\right)$ Terhadap Pendapatan Petani Karet}

Nilai t hitung luas lahan positif 7,290 dan nilai sig $0,000<0,05$ dengan nilai koefisien regresi variabel luas lahan $\left(\mathrm{x}_{1}\right)$ bernilai positif, yaitu 0,397 . dengan demikian dapat disimpulkan bahwa variabel luas lahan berpengaruh positif dan signifikan terhadap pendapatan total petani penyadap karet. nilai koefisien korelasi positif $(0,397)$ artinya,bahwa setiap peningkatan luas lahan sebesar nilai.1 maka tingkat pendapatan petani karet akan meningkat sebesar Rp.0, 397 dengan asumsi variabel independen lain nilainya tetap.

Pengaruh Pengalaman Kerja ( $\left.\mathbf{X}_{2}\right)$ Terhadap Pendapatan Petani Karet

Nilai $\mathrm{t}$ hitung pengalaman kerja positif 1,818 dan nilai sig $0,074>0,05$ dengan nilai koefisien regresi variabel pengalaman kerja $\left(\mathrm{x}_{2}\right)$ bernilai positif, yaitu 0,098. dengan demikian dapat disimpulkan bahwa variabel pengalaman kerja berpengaruh positif dan tidak signifikan terhadap pendapatan total petani penyadap karet. nilai koefisien korelasi positif $(0,98)$ artinya,bahwa setiap peningkatan pengalaman kerja sebesar nilai.1 maka tingkat pendapatan petani karet akan meningkat sebesar Rp.0,098 dengan asumsi variabel independen lain nilainya tetap. 


\section{Pengaruh Umur karet $\left(\mathbf{X}_{3}\right)$ Terhadap Pendapatan Petani Karet}

Nilai t hitung umur karet positif 1,375 dan nilai sig $0,175>0,05$ dengan nilai koefisien regresi variabel umur karet $\left(\mathrm{x}_{3}\right)$ bernilai positif, yaitu 0,061 . dengan demikian dapat disimpulkan bahwa variabel umur karet berpengaruh positif dan tidak signifikan terhadap pendapatan total petani penyadap karet. nilai koefisien korelasi positif variabel umur karet $\left(\mathrm{x}_{3}\right)$ bernilai positif, yaitu 0,061. artinya,bahwa setiap peningkatan umur karet sebesar nilai.1 maka tingkat pendapatan petani karet akan meningkat sebesar Rp.0,061 dengan asumsi variabel independen lain nilainya tetap.

\section{Pengaruh Hari kerja $\left(\mathbf{X}_{4}\right)$ Terhadap Pendapatan Petani Karet}

Nilai t hitung hari kerja positif 12,516 dan nilai sig $0,000<0,05$ dengan nilai koefisien regresi variabel hari kerja $\left(\mathrm{x}_{4}\right)$ bernilai positif, yaitu 0,061. dengan demikian dapat disimpulkan bahwa variabel hari kerja berpengaruh positif dan signifikan terhadap pendapatan total petani penyadap karet. nilai koefisien regresi variabel hari kerja $\left(\mathrm{x}_{4}\right)$ bernilai positif, yaitu 1,194. Artinya,bahwa setiap peningkatan hari kerja sebesar nilai.1 maka tingkat pendapatan petani karet akan meningkat sebesar Rp. 1,194 dengan asumsi variabel independen lain nilainya tetap.

\section{Hasil Uji Koefisien Regresi Secara Bersama}

Hasil uji koefisien regresi secara bersama diperoleh nilai $\mathrm{F}$ hitung sebesar $\mathrm{F}=86,552$ dengan $\mathrm{f}$ tabel $(\mathrm{df}=\mathrm{N}-\mathrm{K}-$ 1 ) dimana $\mathrm{df}=61-5-1=55$, jadi $\mathrm{f}$ tabel $=2,38$ ( $\mathrm{f}$ hitung $>\mathrm{f}$ tabel $)$, sementara signifikansi $0,000,(0,000<$ 0,05) maka dapat disimpulkan bahwa variabel luas lahan, pengalaman kerja, umur karet dan hari kerja secara bersama-sama berpengaruh signifikan terhadap pendapatan total petani karet.

\section{KESIMPULAN}

Berdasarkan hasil penelitian dan analisa data yang telah dilakukan maka diambil kesimpulan penelitian sebagai berikut :

1. Persamaan pendapatan total/TR petani penyadap Karet di Desa Banua Tengah adalah sebagai berikut $\ln \mathrm{Y}=9,817+0,397 \mathrm{X}_{1}+0,098$ $\mathrm{X}_{2}+0,061 \mathrm{X}_{3}+1,194 \mathrm{X}_{4}$

Dengan nilai korelasi $\mathrm{R}=0,928^{\mathrm{a}}$ serta nilai determinasi $\mathrm{R}^{2}=0,861$ atau $86,1 \%$. Dari persamaan tersebut diperoleh nilai konstanta sebesar 9,817 pada model persamaan menunjukan bahwa pendapatan total/TR petani karet $(\hat{Y})$ di Desa Banua Tengah adalah sebesar Rp 9,817 jika $X_{1}, X_{2}, X_{3}$ dan $X_{4}$ dianggap nol. Dari persamaan tersebut dapat dilihat bahwa $\hat{Y}$ berkolerasi positif terhadap $\mathrm{X}_{1}, \mathrm{X}_{2}$, $\mathrm{X}_{3}$ dan $\mathrm{X}_{4}$.

2. Keempat faktor yang diduga mempengaruhi pendapatan petani karet di Desa banua Tengah yang berpengaruh secara signifikan adalah Variabel Luas lahan dan jumlah hari kerja petani penyadap karet. Sedangkan variabel pengalaman kerja dan umur karet tidak berpengaruh secara signifikan.

3. Faktor lus lahan, pengalaman kerja, umur karet, dan hari kerja secara bersamaan sangat mempengaruhi pendapatan petani.

\section{SARAN}

Faktor luas lahan dan jumlah hari kerja petani penyadap karet sangat berpengaruh terhadap pendapatan petani, dengan demikian semakin luas lahan yang dimiliki serta semakin banyak hari kerja para petani maka, pendapatan petani akan meningkat. 
Perlu adanya pembuatan organisasi atau lembaga khusus untuk pengembangan usaha tani mengingat

\section{DAFTAR PUSTAKA}

Almasdi Syahza,. 2015. Ekonomi Pembangunan, Teori dan Kajian Empirik Pembangunan Pedesaan, Pekanbaru : Universitas Riau.

Boerhendhy, Island dan Amypalupy, Khaidir 2010. Optimalisasi Produktivitas Karet Melalui penggunaan Bahan Tanam, Pemeliharaan, Sistem Eksploitasi, dan Peremajaan Tanaman. Balai Penelitian Sembawa, Banyuasin dalam Jurnal Litbang Pertanian, 30 (1), 2011. Halaman 23.

IRSG 2007. The World Rubber Industri. International Rubber Study Group (IRSG). November 2007

[ITTO] International Tropical Timber Organization. 2011. Potensi Tengkawang di Lahan Masyarakat Lokal Kalimantan Barat. Forestry Research and Development Agency (FORDA) Ministry Of Forestry. http://fordamof.org/files/Brief\%20Info $\% 20 \mathrm{~N}$ 0.4\%20November\%202011.pdf [Diakses tanggal 5 Maret 2019].

Nachrowi dan Hardius. U. 2006. Pendekatan Populer dan Praktis Ekonometrika Untuk Analisis Ekonomi dan Keuangan. Lembaga Penerbit Fakultas Ekonomi Universitas Indonesia.

Priyatno D. 2010. Paham Analisis Statistik Data dengan SPSS. MediaKom. Yogyakarta.

Priyatno D. 2018. Panduan SPSS Mudah Olah Data Bagi Mahasiswa \& Umum. ANDI (Anggota IKAPI). Yogyakarta. pendapatan dari usaha tani di Desa Banua Tengah masih sangat rendah.

Sugiharsono dan Wahyuni D. 2019. Dasar-Dasar Ekonomi. Rajawali Pers.Depok

Suraini Wati, Lumangkun Agustine, Haryani Uke Natalina .2015, Analisa Ekonomi Petani Pengelola Karet (Studi Kasus Di Kawasan Tembawang Kelurahan Sebalo Kec. Bengkayang), Jurnal Hutan lestari. 3 (4) : 507 - 516

Tim Penulis PS. 1999. Karet Straegi Pemasaran Tahun .2000. Budidaya dan Pengolahan. Penebar Swadaya. Jakarta.

Ulfah Diana, Thamrin Gt,A,R, dan Natanael Try Winbert. 2015. Pengaruh Waktu Penyadapan dan Umur Tanaman Karet Terhadap Produksi Getah (lateks). Jurnal Hutan Tropis 3 (3.) Fakultas Kehutanan Universitas Lambung Mangkurat.

Wijayanti T, Saefuddin. 2012. Analisis Pendapatan Usahatani Karet (Hevea Brasilliensis) Di Desa Bunga Putih Kecamatan Marang Kayu Kabupaten Kutai Kartanegara. Jurnal Ziraa'ah, 34 (2) Juni 2012. 